\title{
Land Use Changes in Ciudad Juárez, Chihuahua: A Systems Dynamic Model
}

\author{
Sergio Peña* and César M. Fuentes**
}

\begin{abstract}
The objective of this article is to offer a model to simulate land use changes in Ciudad Juárez, Chihuahua, Mexico. The city faces serious challenges posed by accelerated demographic and urban growth. In its struggle to respond to urban land development pressures, governments, planning agencies and social civil organizations are overwhelmed by a multitude of concerns. The analysis of land use change revolves around two central and interrelated questions: What drives/ causes land use change? What are the environmental and socio-demographic impacts of land change? The land use changes are approached as a complex system in which the elements that define the system and how these relate to each are identified. The development of dynamic simulation models that allow for the generation of different scenarios can be an important tool for urban planning. The software used to simulate the land uses changes is Stella ${ }^{\circledR}$. The results of the model simulated the demand for land among different land uses (commercial, industrial and residential) in the next 10 or 20 years.

Key words: land use changes, system of dynamic model, Stella, Ciudad Juárez
\end{abstract}

Resumen. El objetivo de este artículo es ofrecer un modelo para simular los cambios de uso del suelo en Ciudad Juárez, Chihuahua. La ciudad enfrenta serios retos debido al rápido crecimiento demográfico y urbano que experimenta, lo cual ha preocupado a los gobiernos, las oficinas locales de planificación urbana y organizaciones de la sociedad civil (OSC). El análisis de los cambios en el uso del suelo se relaciona con dos preguntas centrales que se sobreponen: ¿Cuáles son las principales causas de cambios en el uso del suelo? y ¿Cuáles son los impactos del medio ambiente y las variables sociodemográficas en el cambio del uso del suelo? El cambio en el uso del suelo lo abordamos como un sistema complejo e identificamos los elementos que definen el sistema y cómo éste se relaciona en su conjunto. El desarrollo de un modelo de simulación dinámica que permite generar distintos escenarios puede ser una herramienta importante para la planificación urbana. El programa de cómputo usado para simular los cambios en el uso del suelo es Stella ${ }^{\circledR}$. Los resultados del modelo permiten simular la demanda de suelos de los distintos usos (comercial, industrial y residencial) en los próximos 10 o 20 años.

Palabras clave: cambios en el uso del suelo, modelos de simulación dinámica, Stella, Ciudad Juárez

* Assistant Profesor at the University of Texas at El Paso. E-mail: spena3@utep.edu.

** Rescarcher at El Colegio de la Frontera Norte. E-mail: cfuentes@colef.mx. 


\section{Introduction}

The objective of this study is to offer a model to forecast land use changes in Ciudad Juárez, Mexico. It is also our aim that this forecasting tool will be of use for local city planners to begin thinking about future policies regarding where to accommodate future growth and how to manage urban sprawl.

The analysis of land use change revolves around two central and interrelated questions: What drives/causes land use change? What are the environmental and socio-economic impacts of land change? The socio-economic drivers comprise demographic, social, economic, political and institutional factors and processes such as population and population change, property rights, etc. In this context, Ciudad Juárez faces serious challenges posed by faster demographic and economic growth. In its struggle to respond to urban land development pressures, local institutions, both public and private, are overwhelmed by a multitude of concerns.

The article analyzes the relationships among economic variables (US economy and industrial employment), demographics (population growth), and land uses (residential, industrial and commercial). A long-term analysis (to year 2020) will be offered. The results of the model show a reasonable fit between the predicted and the real data.

The article is organized as follows. The first part offers a historical overview of urbanization patterns in Ciudad Juarez to help put this study into perspective. The second part presents a discussion of the characteristics of a dynamic approach and how it differs from other approaches. The next section presents the conceptual model of land use changes. The fourth section presents the model developed in the Stella ${ }^{\circledR}$ software environment followed by an operationalization of the conceptual model in the programming algorithms of Stella ${ }^{\circledR}$ software. The fifth part discusses the results obtained with the simulation of the different scenarios. The sixth presents the conclusions where we emphasize the importance of this exercise for urban planning and policy issues. 


\section{Urbanization Patterns in Ciudad Juárez}

After the Mexican Revolution of 1910, the city began to experience population pressures as a result of immigration flows from central Mexico. By 1921, the population of Ciudad Juárez was growing at an annual rate of $5.5 \%$ and reached a population of almost 20,000 inhabitants. In the next decade the population nearly doubled and the urban area encompassed 471 hectares. ${ }^{1}$ During the 1930s the density fell from 482 to 85 inhabitants per hectare. In the 1940s, these indicators slowed their pace. Ciudad Juárez's population growth average annual rate was only $2.0 \%$ and the urban area increased only by an additional 92 hectares (Fuentes, 2000).

Beginning in the 1950s, the city embarked on a phase of spatial expansion. Ciudad Juárez experienced the highest rate of population growth in its history, mainly as a result of immigration flow due to the repatriation of Mexicans at the end of the Bracero program ${ }^{2}$ in the US and settlement policies of the Mexican government to populate the almost empty northern part of the country through land reform and irrigation policies to expand agriculture. Population grew by $9.2 \%$ from year to year and its urban area expanded to encompass 800 hectares with a population density of 164 inhabitants per hectare. The city continued to grow at a high population rate of $7.2 \%$ in 1960 and its urban area reached 1,894 hectares (Table 1).

From 1960 to 1970, the population again almost doubled from 276,995 to 424,135 , but the size of the urban area grew threefold. The urban area increased from 1,894 hectares in 1960 to 5,608 hectares in 1970 , having an annual growth rate of $10.8 \%$. The population density decreased from 146 inhabitants per hectare in 1960 to 75 inhabitants per hectare in 1970 (Fuentes, 2000). In others words, during this decade the city inaugurated a pattern of urban sprawl. Leap frog development,

\footnotetext{
${ }^{1} 1$ hectare $=2.47$ acres

2 The bracero (arms) program was implemented during World War II. Mexican workers were given permits to work in US agriculture to deal with the shortage of labor due to military duties. After the war Mexicans were repatriated to open up working options to the American soldiers returning from the war.
} 
Table 1.

Historical Growth Ciudad Juárez,

Chihuahua (1990-2005)

\begin{tabular}{lrccr}
\hline Year & Population & $\begin{array}{c}\text { Population } \\
\text { Growth Rate } \\
\text { Annual }\end{array}$ & $\begin{array}{c}\text { Urban Area } \\
\text { (hectares) } \\
\text { (pop/ha) }\end{array}$ & $\begin{array}{c}\text { Population } \\
\text { Density }\end{array}$ \\
\hline 1900 & 8218 & 3.5 & 61 & 134 \\
1910 & 10621 & 2.5 & 119 & 89 \\
1921 & 19457 & 5.5 & N.D & N.D \\
1930 & 39669 & 7.9 & 471 & 84 \\
1940 & 48881 & 2.0 & 563 & 87 \\
1950 & 131308 & 9.1 & 800 & 164 \\
1960 & 276995 & 7.2 & 1894 & 146 \\
1970 & 424135 & 5.2 & 5608 & 75 \\
1980 & 567365 & 4.4 & 9395 & 60 \\
1990 & 798499 & 3.4 & 14049 & 57 \\
1995 & $1^{\prime} 011786$ & 4.3 & 19177 & 53 \\
2000 & $1^{\prime} 217818$ & 4.2 & 21572 & 56 \\
2005 & $1^{\prime} 313338$ & 1.5 & 31246 & 42 \\
\hline
\end{tabular}

Source: Own elaboration based on the Population Census (INEGI) 1980, 1990, 2000 and the Conteo de Población (INEGI), 2005.

development farther away from the center, and hillside squatter settlements lacking services contributed to the problem.

During the next decades the trend continued, the urban area growing at a faster rate than the population, therefore, density continued declining. The city population increased from 567,365 inhabitants in 1980 to 798,499 inhabitants in 1990 . The urban land reached 9,395 hectares in 1990 and the population density continued declining to 57 inhabitants per hectare.

In 1995 the total urban area occupied 18,767 hectares of land. Residential uses consumed about $44 \%$ or about 8,416 hectares, industrial uses only $6 \%$ for a total of 1,209 hectares, commerce and services 1,075 hectares $(5.7 \%)$, mixed use 617 hectares (3.3\%). Open spaces 446 hectares $(2.4 \%)$, internal roads 4,785 hectares $(25.5 \%)$ and vacant urban land 2,219 hectares (11.9\%). Residential uses and roads, which are 
intrinsically linked, account for almost three quarters of the urban land use of the city. From 1995 to 2001 the annual growth rate of residential land was $3.4 \%$, however, industrial and commercial land grew at a faster pace $-8.4 \%$ and $8.2 \%$ respectively. In absolute terms, from 1995 to 2001 residential use increased 1,576 hectares, industrial use 635 hectares, commerce and service use 563 hectares, open spaces 159 hectares, roads 225 hectares and vacant land 281 hectares.

Table 2 shows that in relative terms the residential use of land has comprised a similar proportion since 1995. However, industrial land use has increased its proportion from $6.44 \%$ in 1995 to $8.34 \%$ in 2001; the commerce and service land area has increased from $5.7 \%$ to 7.40 percent.

Cities with significant population growth and housing demand require substantial quantities of land for development. Table 3 shows trends in the conversion of vacant land to residential, industrial and commercial uses. The data indicate that land conversion can be substantial. From 1995 to 2001, residential land use increased 262 hectares per annum, industrial land use 105, and commercial and services 93.5. Urban growth in Ciudad Juárez converts about 180 hectares of agricultural land per year, depending on the extent to which

Table 2.

Land Use in Ciudad Juárez (1995 and 2000)

\begin{tabular}{lrrrr}
\hline Land Use & $\begin{array}{c}1995 \\
\text { Surface } \\
\text { (hectares) }\end{array}$ & Percent & \multicolumn{1}{c}{$\begin{array}{c}2000 \\
\text { Surface } \\
\text { (hectares) }\end{array}$} & Percent \\
\hline Residential & 8416 & 44.8 & 9992 & 45.0 \\
Industrial & 1209 & 6.4 & 1844 & 8.3 \\
Commercial & 1075 & 5.7 & 1638 & 7.4 \\
Mix & 617 & 3.2 & 503 & 2.2 \\
Open Spaces & 446 & 2.3 & 605 & 2.7 \\
Roads & 4785 & 25.5 & 5040 & 22.7 \\
Vacant Land & 2219 & 11.8 & 2500 & 11.3 \\
Others & 18767 & 100.0 & 22122 & 100.0 \\
Total & & & & \\
\hline
\end{tabular}

Source: Plan Director de Desarrollo Urbano, IMIP, 1995, 2000. 
Table 3.

Annual Urban Land Conversion in Ciudad Juárez

\begin{tabular}{lcc}
\hline Land Use & Period & Hectares \\
\hline Residential & $1995-2001$ & 262 \\
Industrial & $1995-2001$ & 105 \\
Commercial & $1995-2001$ & 93.5 \\
Roads & $1995-2001$ & 42.5 \\
\hline
\end{tabular}

Source: Own elaboration, based on Plan Director de Desarrollo Urbano, IMIP, 1995, 2001.

new population can be accommodated through redevelopment and densification.

\section{1) Residential Land}

Based on the previous discussion, the relationship between population and residential land was made clear. The demand for residential land expands due to increases in household formation and income. High population growth and household formation rates increase the demand for housing. Table 4 illustrates household formation and housing production trends in some Mexican cities. It shows the rapid increase in household formation that is common in fast-growth cities such as Ciudad Juárez. For example, annual rates of household formation range from 4 to $6 \%$ per year for the border cities. In non-border cities the annual rate of household formation ranges from 1 to $4 \%$ per year.

Fast-growing cities like Ciudad Juarez tend to consume more land through both outward expansion as well as using urban land more intensively through redevelopment. Population density gradients, which measure population density by distance, illustrate how these patterns change as a city grows. In most cities with well-functioning land markets, the intercept values (that is, the population density at the center of the city) decrease as commercial users take over these areas and residential development and households move to suburban areas. In Ciudad Juárez, population density of the center is the lowest, reaching 


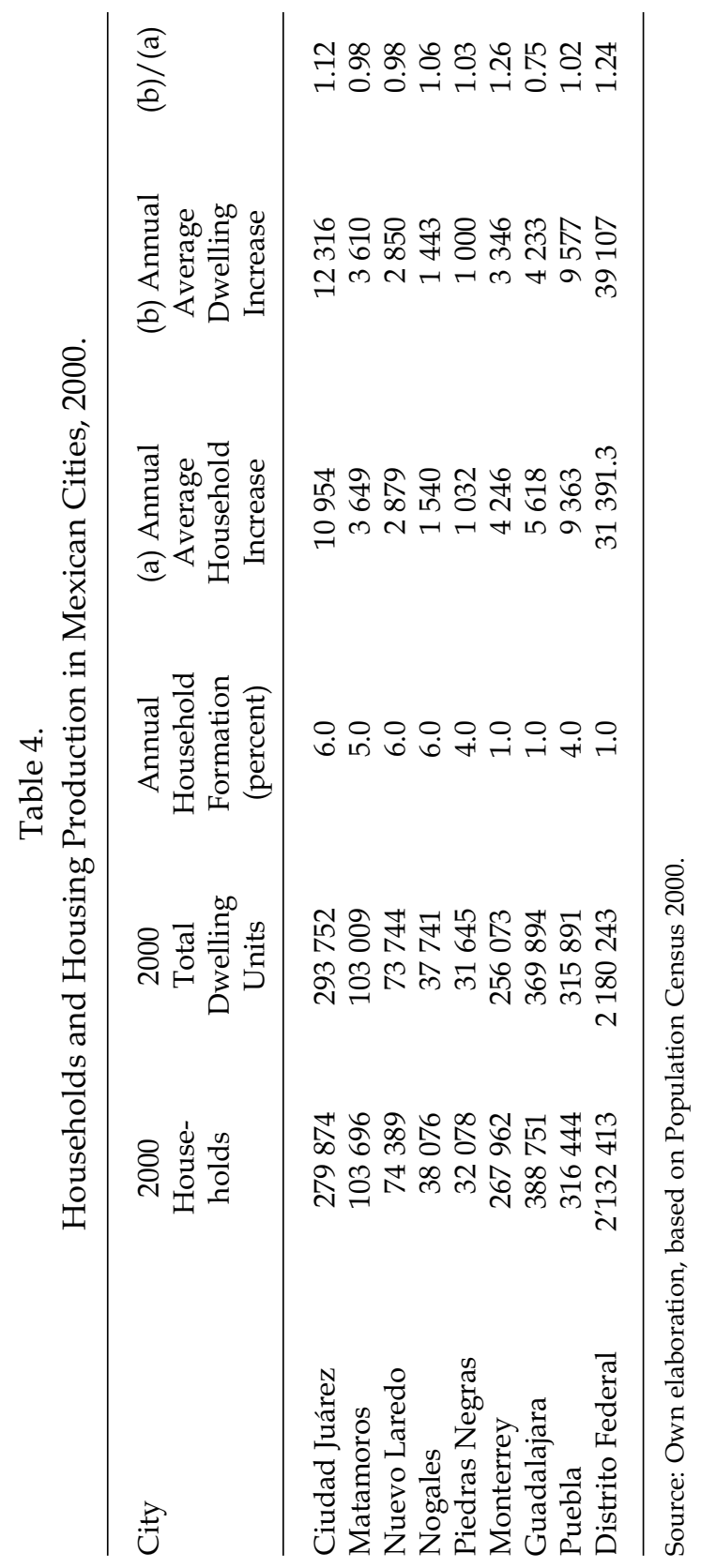


Table 5.

Population Density Gradient (2000)

\begin{tabular}{lcc} 
Urban Hierarchy & $\begin{array}{c}\text { Distance from the Center } \\
\text { Sq. Meter }\end{array}$ & $\begin{array}{c}\text { Population Density } \\
\text { Inhabitants/Hectare }\end{array}$ \\
\hline Center & 0 & 44 \\
Subcenter & 50 & 53 \\
Specialized Center & 150 & 90 \\
Neighborhood Center & 200 & 71
\end{tabular}

Source: Fuentes, 2001.

44 persons per hectare. However, the population density of the suburban areas ranges from 70 to 90 persons per hectare (Table 5).

\section{2) Industrial Land}

As stated before, the adoption of the BIP program in the late 1960s was the inflection point towards a new economic regime in Ciudad Juárez. By the 1980s, Mexico shifted its development strategy from an import substitution model to an export led model where maquiladoras play a very important role. As a consequence of these economic policies, the city experienced broad-based industrial change as the number of maquiladoras expanded. Based on historical data, about 17 square meters of space are needed to accommodate each additional job in the maquiladora industry (AMPI, 2000). In Ciudad Juárez the real estate market for industrial facilities is estimated at about 4 million square meters of space, making of this city one of the largest markets of industrial facilities in the country (Figure 1).

The largest developers in this area are Intermex, Prologis (Formerly Security Capital), Cambridge, and Bermúdez. The Bermúdez Group owns and operates 4 industrial parks - Bermúdez, Río Bravo, Panamericano, and Los Aztecas in its current portfolio of 3.5 million square feet (about 325,000 square meters) of industrial space (Table 6). This is a family owned and operated business since 1954, and rated as one of the largest developers in northern Mexico. The Intermex Group is the 
Figure 1.

Market Size of Industrial Facilities by Cities

(Million of $\mathrm{ft}^{2}$ )

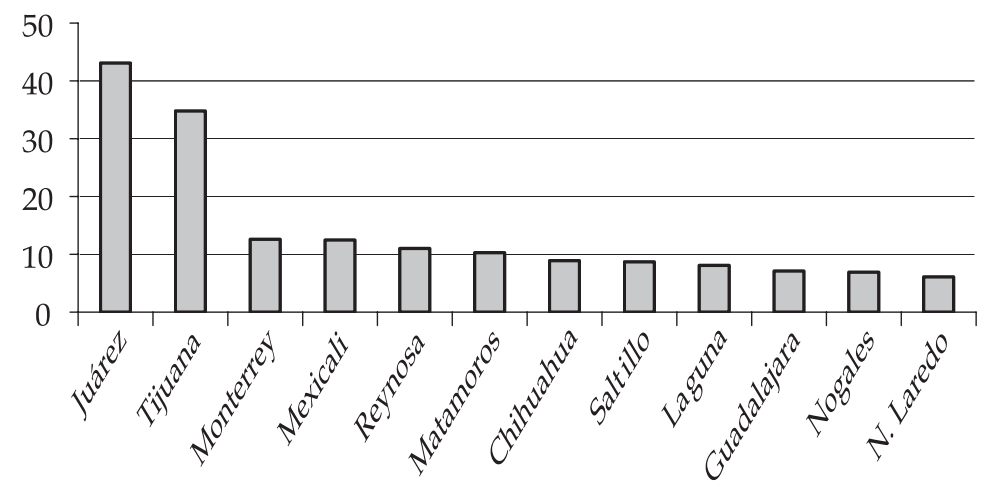

Source: Asociación Mexicana de Parques Industriales, 2000.

second in importance; it developed and owns three industrial parks - Gemma I, Gemma II, and Juárez. This industrial group developed 90 hectares since 1971. ProLogis group owns two industrial parks - Salvarcar and Southwest - the total square feet available is 76,115 (about 7000 square meters). Chihuahua's state government developed Complejo Industrial Aeropuerto (72 hectares) as a vehicle to attract maquiladoras.

\section{3) Commercial and Service Land}

The commercial and services sectors, which traditionally constituted the urban center in the central business district, began a phase of expansion along the main roads that connected the historic downtown to the eastern part of the city. This resulted in the formation of a new central business district that is also located along the main roads (Fuentes, 2001). The new district was rooted in urban sprawl during the 1970s and 1980s. Industrial and residential growth toward the northeast also demanded a new central business district. Within this context, a new zone emerged with housing, large shopping centers 
and restaurants. The appearance of this new zone reflects a change from activities surrounding tourism to those related to business. From 1995 to 2001, the land with commerce and service uses increased by 563 hectares.

The traditional pattern of centralization in commercial and service land use is modified as a result of four processes: 1) greater competition between regional, national, and international commercial corporations having as a result the southward relocation of warehouses near residential areas, 2) deficient public transportation, 3) substantial

Table 7.

Number of Maquiladora Industrial Parks by size in Ciudad Juárez, 2000.

\begin{tabular}{|c|c|c|c|}
\hline Industrial Park & $\begin{array}{c}\text { Total } \\
\text { Surface } \\
\text { (hectares) }\end{array}$ & $\begin{array}{c}\text { Surface } \\
\text { Constructed } \\
\text { (hectares) }\end{array}$ & $\begin{array}{c}\text { Number of } \\
\text { Industrial } \\
\text { Plants }\end{array}$ \\
\hline Antonio J. Bermúdez & 174 & 139 & 51 \\
\hline Río Bravo-Beffer & 77 & 65 & 16 \\
\hline Panamericano & 31 & 19 & 8 \\
\hline Los Aztecas & 36 & 29 & 9 \\
\hline Los Fuentes & 57 & 23 & 10 \\
\hline Salvarcar & 26 & N.D & 7 \\
\hline Zaragoza & 99 & 31 & 24 \\
\hline Fernández & 12 & N.D & N.D \\
\hline Gemma I & 40 & 38 & 9 \\
\hline Gemma II & 10 & 5 & N.D \\
\hline Juárez & 40 & N.D & 15 \\
\hline Internacional Mexicano & 81 & 20 & 8 \\
\hline Omega-Magnaplex & 76 & N.D & 20 \\
\hline C. Ind. Aeropuerto & 72 & N.D & 14 \\
\hline Aero-juárez & 70 & 20 & N.D \\
\hline C. Ind. Médanos & 468 & 0 & N.D \\
\hline Las Américas & 23 & 6 & 1 \\
\hline El Dorado (Project) & 19.5 & 0 & 0 \\
\hline Northgate (Project) & 29 & 0 & 0 \\
\hline Total & 1,440 & 394 & 192 \\
\hline
\end{tabular}

Source: CIES, 2000. 
investment in freeways, and 4) exhaustion of the agglomeration economies of the central business district (Fuentes, 2001).

As previously shown, demographic and economic factors drive urbanization; therefore, urban development policies to a great extent are mechanisms to allocate and accommodate a variety of urban activities such as residential, industrial, commercial, etc. In this context, the following sections deal with the development of a model to simulate future land developments.

\section{System Dynamics Models}

Modeling has been an endeavor that has caught the attention of social scientists. A classical definition of a model is the one put forward by Lowrey (1965), which defined a model as "a simplification" (cited in Batty, 2003). The objective is to take a given complex system and identify the elements that define the system and how these relate to each other. Furthermore, the objective of modeling must also be pedagogical in the sense that the modeler and users can learn about "actions, reactions, causes, and consequences" (Guhathakurta, 2003: 7). In sum, it is our intention to contribute to the understanding of the driving forces behind the growth and allocation of land.

The evolution and growth of systems models goes hand in hand with the advent of personal computers (PC). According to Gilbert and Troitzsch (2002: 17), most of the modeling prior to PCs was reduced to differential equations; simulation models are more concerned with understanding processes whereas statistical models, such as differential equations, focus on correlations. Systems models thus are preferable because they allow for theory testing and exploration. As PCs became more affordable and increased their processing power, efforts to develop more complex models increased and specialized software able to process a great deal of information, such as Stella ${ }^{\circledR}$, became available.

According to Axelrod (1997) there exist two sets of models -rational-choice and agent-based models. A first set of models includes typical equilibrium models used in game theory and rational-choice which begin by "specifying a set of axioms and proving consequences 
that can be derived from those assumptions" (Axelrod 1997: 3). These models assume that the actors behave rationally, choosing only strategies that would optimize outcomes. In contrast, agent-based models assume that the actors adapt their behavior instead of choosing optimal strategies; that is, the actors learn by doing.

Grant et al. (2001) point to different methods to identify the kind of "puzzle" that the researcher wants to solve. The method consists of identifying the components or variables that will be included in the model and the relation among the components. The researcher will try to solve puzzles. A first type is characterized by an unorganized complexity where several components exist and there is little understanding of how they relate. Another example is a system of organized complexity, where fewer components exist and there is a good understanding of how they relate to each other. In between these two methods exists organized complexity, where some understanding exists among the components and how they relate. Land use in Ciudad Juarez is a typical example of organized complexity where there is a good deal of understanding of the components (demographic and economic) and how they relate as the next section will show.

\section{Conceptual Model of Land Use Change in Ciudad Juarez}

In the modeling process, according to Gilbert and Troitzsch (2002), after the "puzzle" has been identified (what factors drive the urban growth process in Ciudad Juárez?), the next step will be to design a model. Ciudad Juárez has undergone enormous population and physical growth due to two interrelated factors -industrialization and population growth, mainly through migration. This is especially true since 1970, when the city experienced faster population growth than any other border city and became home to the second largest concentration of maquiladoras in the country (INEGI, 2000).

Employment is the indicator that best captures the close relationship between economic and demographic factors. Ciudad Juárez has more maquiladora employment than any other border city. The dramatic growth makes the maquiladora economy a prime catalyst for urban 
change. The model presented here draws on the linkages between maquiladora employment and land use change.

In order to understand the dynamics of land use changes, it is important to take into account the interdependence among different urban land uses. Lowry's land allocation model (Lowry, 1964; Garin, 1966) provides an excellent conceptual framework for capturing these interdependencies because it describes how change in one land use precipitates change in other land uses - for instance, how employment growth affects residential land and how new developments, in turn, need commercial and services related functions.

In the contemporary context of Ciudad Juárez (1970 to present), maquiladora employment is the key force that induces change in the allocation of land within the city. Once maquiladoras arrived, the demand for industrial uses increased. Initially, the available local labor is employed but due to the rapid influx of maquiladora plants, each employing hundreds of workers (on average), additional "outside" labor is needed. This leads to migration and overall urban population growth. The inflow of labor increases the demand for residential land as workers and their families seek housing. Vacant housing units are initially filled, but the escalating number of immigrants leads to the development of new residential districts. Population growth also induces demand for commercial activities (defined broadly to include wholesale, retail and business/personal services). The demand for commercial activities leads to the expansion of commercial establishments already in place as well as the formation of new enterprises so that the amount of commercial land rises. The expansion of the commercial sector creates more employment and these employees require additional residential land (Figure 2). Finally, farm and desert land are the main suppliers of land to accommodate the urban growth.

\section{Model Operationalization}

Continuing with the Gilbert and Troitzsch (2002) methodology, once the model has been designed, the next step will be to build the model 
Figure 2.

Model of Land Use Change in Ciudad Juárez

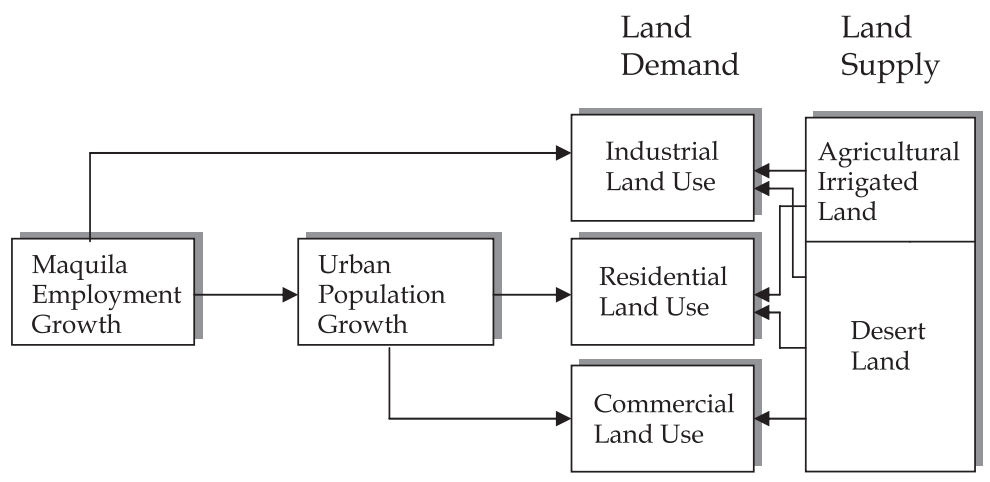

with the assistance of a computer program or software. The model in this article is operationalized using the Stella ${ }^{\circledR}$ software developed by High Performance Systems Corporation.

Stella ${ }^{\circledR}$ software employs only four types of states. The boxes represent stocks that increase or decrease. The stock increases as a result of an inflow or decreases as a result of an outflow; these are represented by the arrows with the knob icon where the flow is regulated. The clouds represent origin or destination of the flow that the model is not particularly interested in explaining. Finally, there exist converters represented by circles named converters, which are the ones that feed the inflows and outflows (Figure 3). The system

Figure 3.

Stella ${ }^{\circledR}$ algorithms

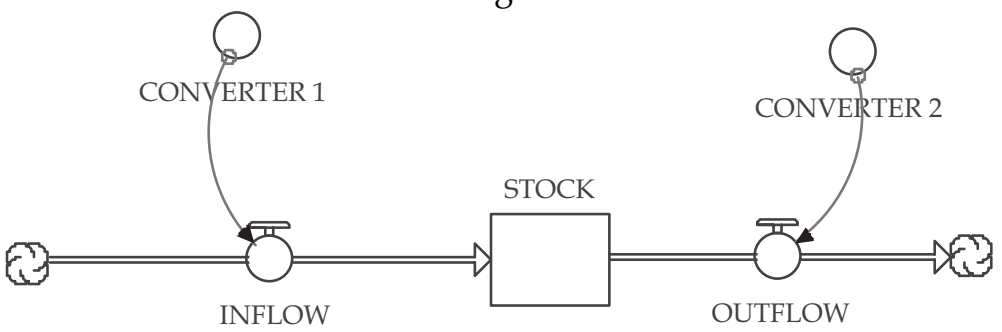


allows us to generate forecasts based upon a dynamic system so that once the user establishes the basic structure of the model, he or she can adjust the rates as sliders to explore different policy options. Among the many advantages of the use of Stella ${ }^{\circledR}$ is that behind the diagram of the model there exists a series of differential equations that the user can use to solve a complex system of equations without possessing extensive knowledge of statistics or mathematics.

In general terms, the land use model is divided basically into three linked sectors. The first sector focuses on modeling the economic sector in Ciudad Juárez (CJ) -specifically in forecasting the growth of industrial employment. The second sector deals with demographic changes. The third sector models urban land changes of industrial, commercial, and residential uses. Figure 4 shows the entire model which in the next paragraphs is explained in more detail.

Figure 4.

CJ Operational Land Use Model

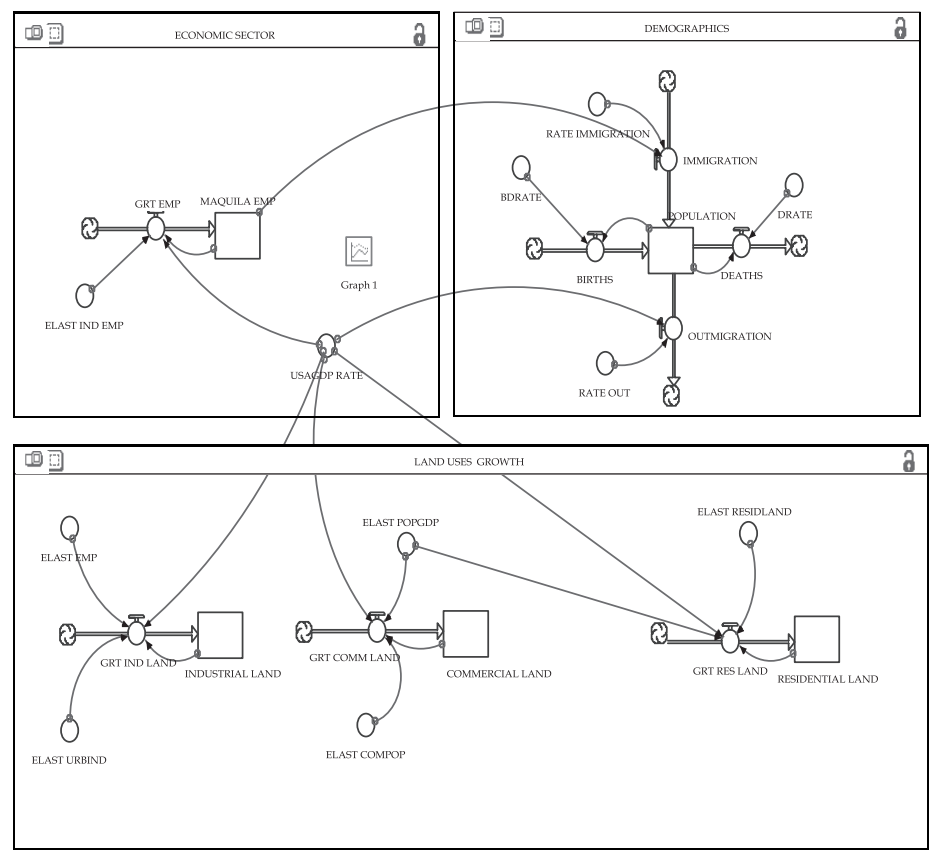


The economic model contains a stock variable that attempts to model the growth of industrial employment (MAQUILA EMP) as a function of the growth of the US economy (USA GDP). The variable ELAST IND EMP (2.774) is a factor that converts the USA GDP into maquiladora employment, measured in the form of elasticity. In other words, if USA GDP increases by $1 \%$, the maquiladora employment will increase by $2.7 \%$. It is important to clarify that this parameter was estimated based on historical data from 1980 to 2000.

The demographic sector models the population growth (POP). Population growth is driven by natural factors, such as births and deaths, and by socioeconomic factors such as immigration and outmigration. Immigration and out-migration are a function of maquiladora employment. It is assumed that for each additional job in the maquiladora industry there is a $5 \%$ probability of a worker migrating; that is, for every 20 new jobs in the maquila, one new migrant arrives to the city. The probability of outmigration is set to $2.5 \%$, which means that if there is a loss of 40 jobs, then one worker leaves the city. The probabilities were calculated through a process known as history matching until parameters are found through different rounds calibrating the model.

The third sector in the model deals with land. The model focuses only on three types of land uses considered to be the most important -industrial, residential and commercial. The model was set in such a way that industrial land use is closely linked to employment in the maquiladora industry which, in turn, is a function of the US economy. The growth of land is the product of the elasticity of industrial employment (ELAST IND EMP) with respect to the US economy and the elasticity of the industrial land with respect to changes in the urban area (ELAST URBIND).

The growth of residential land depends to a great extent on population. It is important to keep in mind that a significant force behind population growth in $\mathrm{CJ}$ is the us economy. The growth of residential land is the product of the growth rate of the US economy (USAGDP RATE) and the rate of change in the population induced by the us economy measured as elasticity (ELAST POPDGP) and the elasticity of residential growth with respect to the urban area (ELAST RESID LAND). 
As in the case of residential land, the growth of commercial land depends on demographic and economic forces. This relationship reflects what was explained previously -that as new neighborhoods emerge, people demand certain goods and services, such as groceries, furniture, construction materials, etc., this in turn will create the opportunity to expand and create new business that the new residential centers and population demand, measured as elasticity(ELAST COMPOP). The other factor is the US economy and its effect on population growth (ELAST POPGDP). All the equations and values are given in the appendix.

\section{Validation of the model}

The model was validated against real data from 1980 to 2000 . The results are presented in Table 8, where the real and estimated data are shown for the five key variables in the model -population, maquiladora employment, and industrial, residential, and commercial land uses.

Table 8 shows the evaluation of the results of the estimated model against the real data. The three variables that presented the biggest margin of error (percent being underestimated or overestimated) are commercial land (9.04\%), employment (-8.02\%) and population (-7.38\%). The variables with the minimum margin of error are residential land (4.58) and industrial land (3.74\%).

The explanation for the errors in the model is that the US GDP was assumed as a constant (3.5\%) as were the industrial land elasticities. However, it is clear that by 2000 the rate of economic growth in the us has slowed. Furthermore, authors such as Carillo and Hualde (1996) had pointed out that the maquildora industry has shifted from highly labor intensive industries, such as textiles, to less labor intensive industries, such as auto design. In other words, the productivity of the labor force has increased, which means fewer people producing more output and, consequently, the demand for industrial land should decline as well.

An advantage that the Stella ${ }^{\circledR}$ software offers is that the parameters can be adjusted to explore different scenarios. A future scenario for 2020 was forecast, changing some of the assumptions and parameters. It is assumed that the pace of the US economy will be slower. Random 


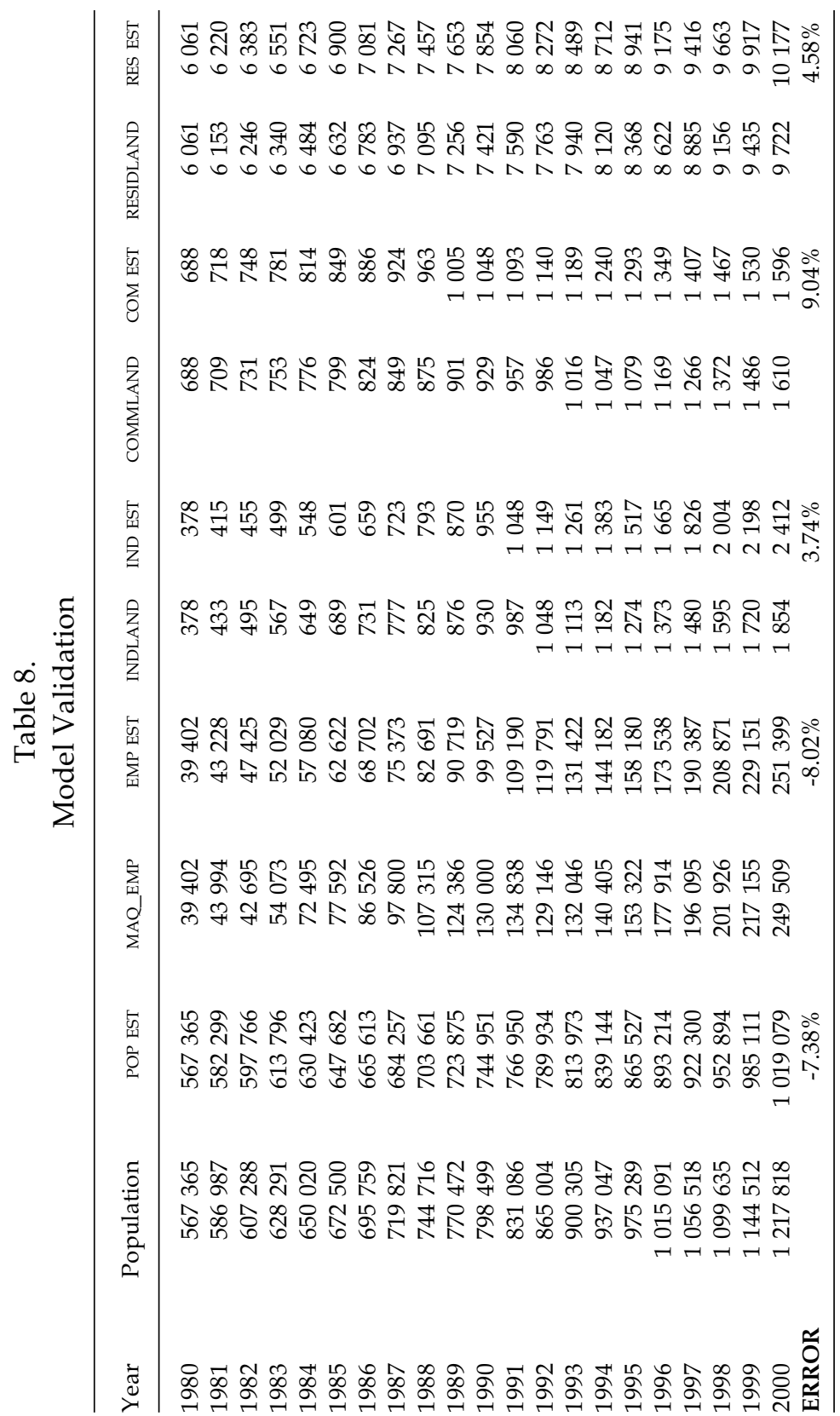


growth between $0 \%$ and $3 \%$ was used given the fact that the historical growth of developed economies in average is about 3\%. Also, it is assumed that the maquiladora industry will continue to shift towards less intensive industries, therefore the employment elasticity was changed from 2.74 to 1.5 , which means that if the US GDP grows by $1 \%$, the level of employment will increase by only $1.5 \%$ instead of the original 2.74 percent.

Table 9 shows the forecast results for the period 2000-2020 for Ciudad Juárez. The model forecast a population of 2275059 which is about a 5\% underestimate than the one by Peach and Williams (2000) in their medium case population forecast of 2395024 . The maquiladora employment is estimated to create an additional 111718 jobs in 20 years, reaching a total of 361227.

In regard to the land use forecast, as expected, residential land will experience the biggest increase overall. According to the model, 1990 additional acres (805 hectares) will be needed to accommodate the population increase. Commercial land will need 571 additional acres (12.1 hectares) to take care of the new residential growth. Finally, as was expected, the growth of industrial land will require only 830 additional acres (37.1 hectares).

\section{Conclusions}

This study has shown that the economic boom of Ciudad Juárez has been related to the maquiladora industry, which at the same time is a reflection of the industrial reorganization of the US economy from fordists into flexible production systems. During two decades beginning in the 1980s, Ciudad Juárez experienced an economic boom that transcended into other social and demographic variables. The urban area of the city expanded from almost 9000 hectares to 22000 and its population grew from almost .5 to 1.2 million in two decades.

In the same way as booms, economic downturns of the us economy have also contributed to the economic uncertainty of Ciudad Juárez. The 2000 recession in the USA translated in the lost 65000 industrial jobs in the city because the engine of growth of the city is an 


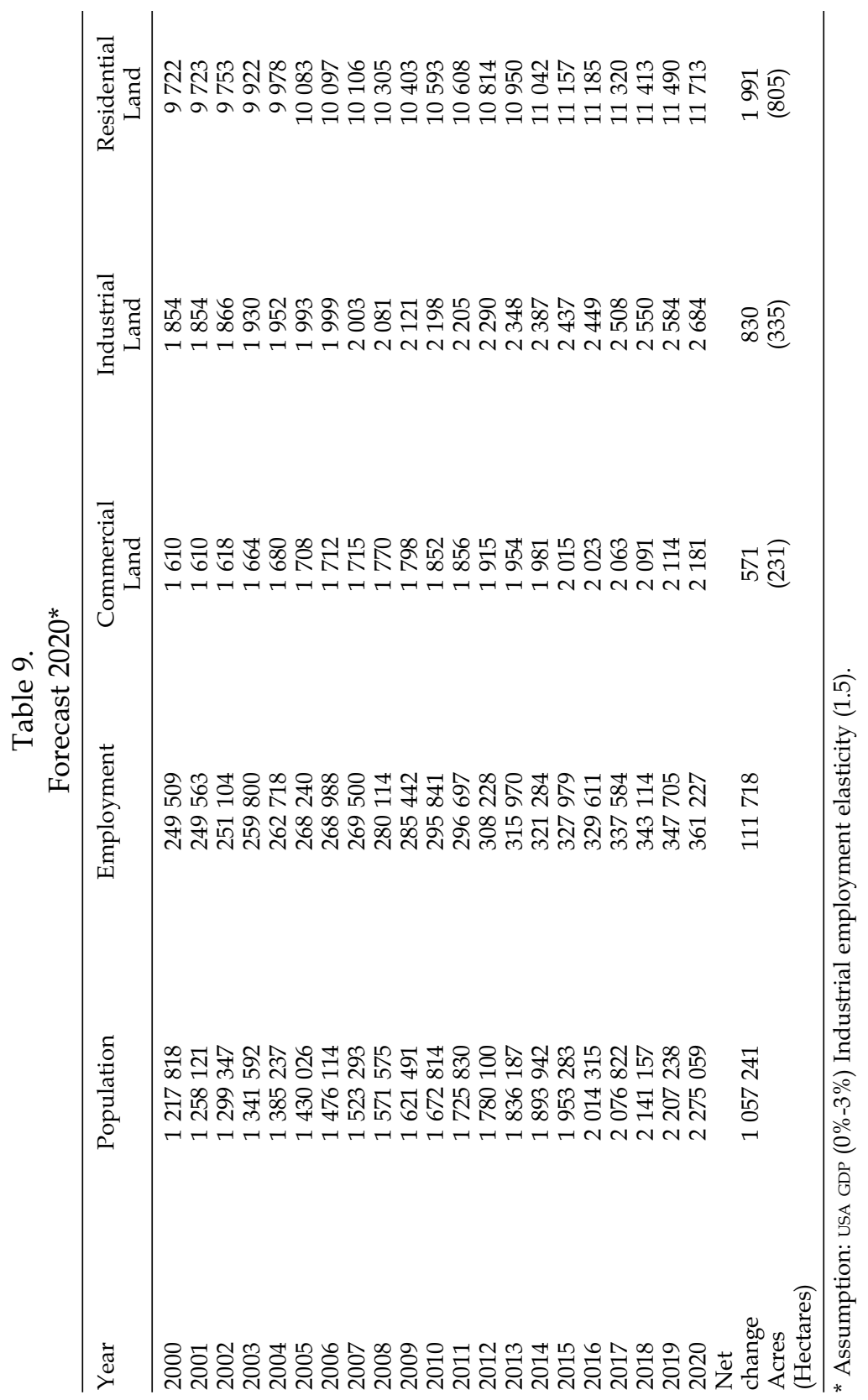


exogenous force -i.e. the US economy. The development of system dynamic models and the simulation of different scenarios can be an important tool for urban planning. An advantage of systems dynamics, such as the one presented here, is that it allows us to develop other types of scenarios, such as a best case scenario where we could assume that the US economy will go back to a high growth path and, therefore, Ciudad Juárez can continue its economic boom, or a worst case scenario, where the US economy stagnates in the next 20 years.

This paper has contributed to developing a model that forecasts key variables in a long-term scenario into 2020. Incorporating systems dynamic is important to guide policy making; the system would allow the policymaker to explore different case scenarios and to observe the result of his/her actions. Furthermore, the policymaker can experiment with different policy options and simulate results by changing the parameters in the model, for instance, the effect of increasing population density on the demand for residential land.

In sum, the model developed here can help planners and policymakers to forecast the demand for land among different land uses in the next 10 or 20 years. As previously stated, the model could help to determine how much land is needed and allocated to the different uses but the locational decision is up to the land use planners or the market. There exist other modeling techniques, such as a cellular automata (CA) or agent based models, that can be used to explore the spatial impacts and the form of the city under the current rules of development and how the city would grow if the rules were changed (Batty, 2003). CA models deal with the geography of development whereas dynamic system models focus on estimating parameters and quantity. So a combination of a dynamic system, such as the one presented here, and a CA model dealing with the geography of development can be the best option as some studies have shown (Batty, 2003). 


\section{Bibliography}

Arreola D. \& J. Curtis (1993), The Mexican Border Cities: Landscape Anatomy and Place Personality, Temple, University of Arizona Press.

Axelrod, R. (1997), The Complexity of Cooperation: Agent-Based Models of Competition and Collaboration, Princeton University Press, Princeton, NJ.

Batty, M. (2003), “New Development in Urban Modeling; Simulation, Representation, and Visualization, "in Subhrajit Guhathakurta (ed.), Integrated Land Use and Environmental Models: A Survey of Current Applications and Research, Springer, New York, NY., 13-44. Carrillo, J. \& A. Hualde. (1996), “Maquiladora de Tercera Generación. El Caso de Delphi-General Motors", Espacios, Revista Venezolana de Gestión Tecnológica, No.6, pp. 79-100.

Esparza A., J. Chavez \& B. Waldorf (2001), "Industrialization and Land Use Change in Mexican Border Cities: The Case of Ciudad Juárez, Mexico", Journal of Borderlands Studies, Vol. XVI, No. 1, Spring. Fuentes, C. (2000), "Urban Function and Its Effect on Urban Structrure: The Case of Ciudad Juárez, Chihuahua", Borderlands Studies, Vol. XV, No. 2, Fall.

(2001), “Los Cambios en la Estructura Intraurbana de Ciudad Juárez, Chihuahua: De Monocéntrica a Multicéntrica", Frontera norte, Vol. 13, No. 25, January-June.

Garin, R. (1966), "A Matrix Formulation of the Lowry Model for Intermetropolitan Activity Allocation", Journal of the American Institute of Planners, 32.

Gilbert, N. \& K.G. Troitzsch (2002), Simulation for the Social Scientists, Open University Press, Philadelphia, PA.

Grant, W.E., S.L. Marin \& E.K. Pedersen (2001), Ecología y Manejo de Recursos Naturales: Análisis de Sistemas y Simulación, Editorial Agroamérica IICA, San José, Costa Rica.

Guhathakurta, S. (2003), Integrated Land Use and Environmental Models: A Survey of Current Applications and Research, Springer, New York, NY. 
Lorey, D.E. (1993), United States-Mexico Border Statistics Since 1900: 1990 Update, UCLA Latin American Center Publication, Los Angeles, CA.

Lowry, I.S. (1964), A Model of Metropolis, RAND Corporation, Santa Monica, Rand Corporation, CA. RM-4305-RC.

Peach, J. \& J. Williams (2000), Population and Economic Dynamics on the U.S.-Mexican Border: Past, Present, and Future, P. Ganster (ed.), pp. 1.37-72, San Diego, SCERP-SDSU.

\section{Other sources}

INEGI (2000), “La Producción, Salarios, Empleo y Productividad de la Industria Maquiladora de Exportación. Total Nacional", Sistema de Cuentas Nacionales de México.

INEGI (2002), Censo de Población y Vivienda 2000.

CIES 2000

Plan Director de Desarrollo Urbano, IMIP, 1995, 2001. 


\section{Appendix (Stella ${ }^{\circledR}$ Algorithms)}

\section{DEMOGRAPHICS}

POPULATION $(\mathrm{T})=$ POPULATION $(\mathrm{T}-\mathrm{DT})+($ BIRTHS + IMMIGRATION OUTMIGRATION - DEATHS) * DT

INIT POPULATION $=567365$

INFLOWS:

BIRTHS $=$ POPULATION ${ }^{*}$ BDRATE

IMMIGRATION $=$ MAQUILA_EMP*RATE_IMMIGRATION

OUTFLOWS:

OUTMIGRATION $=$ IF(USAGDP_RATE $<=0)$ THEN RATE_OUT=.025 ELSE 0 DEATHS $=$ POPULATION ${ }^{*}$ DRATE

BDRATE $=28.3 / 1000$

DRATE $=5.45 / 1000$

RATE_IMMIGRATION $=.05$

RATE_OUT $=.025$

\section{ECONOMIC SECTOR}

MAQUILA_EMP(T) = MAQUILA_EMP(T - DT $)+($ GRT_EMP $) *$ DT

INIT MAQUILA_EMP $=39402$

INFLOWS:

GRT_EMP $=$ MAQUILA_EMP*ELAST_IND_EMP*USAGDP_RATE

ELAST_IND_EMP $=2.774$

USAGDP_RATE $=.035$

\section{LAND USE SECTORS}

LAND USES GROWTH

COMMERCIAL_LAND $(\mathrm{T})=$ COMMERCIAL_LAND $(\mathrm{T}-\mathrm{DT})+$

$$
\text { (GRT_COMM_LAND) }{ }^{*} \text { DT }
$$

INIT COMMERCIAL_LAND $=688$ 


\section{INFLOWS:}

GRT_COMM_LAND =

COMMERCIAL_LAND*ELAST_COMPOP*ELAST_POPGDP*USAGDP_RATE

INDUSTRIAL_LAND $(\mathrm{T})=$ INDUSTRIAL_LAND $(\mathrm{T}-\mathrm{DT})+($ GRT_IND_LAND $)$ * DT

INIT INDUSTRIAL_LAND $=378$

INFLOWS:

GRT_IND_LAND =

INDUSTRIAL_LAND*ELAST_IND_EMP*ELAST_URBIND*USAGDP_RATE

RESIDENTIAL_LAND $(\mathrm{T})=$ RESIDENTIAL_LAND $(\mathrm{T}-\mathrm{DT})+(\mathrm{GRT}$ _RES_LAND) * DT INIT RESIDENTIAL_LAND $=6061$

INFLOWS:

GRT_RES_LAND $=$

RESIDENTIAL_LAND*ELAST_POPGDP*ELAST_RESIDLAND*USAGDP_RATE

ELAST_COMPOP $=1.036$

ELAST_POPGDP $=1.185$

ELAST_RESIDLAND $=.633$

ELAST_URBIND $=1$

Fecha de recepción: junio de 2006

Reenviado en: febrero de 2007

Fecha de aprobación: marzo de 2007 